\title{
SODIUM-CALCIUM INTER-RELATIONSHIPS WITH SPECIFIC REFERENCE TO OSTEOPOROSIS
}

\author{
COLETTE SHORTT* AND ALBERT FLYNN† \\ Department of Nutrition, University College, Cork, Irish Republic
}

CONTENTS

INTRODUCTION

101

PHYSIOLOGICAL BASIS FOR THE RELATIONSHIP BETWEEN URINARY SODIUM AND CALCIUM

EFFECT OF SALT SUPPLEMENTATION ON CALCIUM METABOLISM IN THE RAT.

RELATIONSHIP BETWEEN URINARY SODIUM AND CALCIUM EXCRETION IN MAN.

STUDIES ON FREE-LIVING INDIVIDUALS

104

104

STUDIES WITH CONTROLLED SODIUM INTAKE . . . . . . . . . . 106

MAGNITUDE OF SODIUM-INDUCED CALCIURIA . . . . . . . . . . . 107

INDIVIDUAL VARIABILITY IN URINARY CALCIUM RESPONSE TO DIETARY

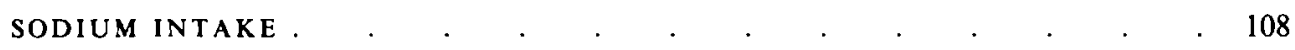

EFFECT OF SODIUM INTAKE ON SERUM PARATHYROID HORMONE,

CALCIUM ABSORPTION AND BALANCE . . . . . . . . . . . . 108

EFFECT OF SODIUM INTAKE ON BONE METABOLISM AND OSTEOPOROSIS IN MAN

CONCLUSIONS

REFERENCES

\section{INTRODUCTION}

Dietary sodium intake has long been known to influence urinary calcium excretion in man (Aub et al. 1937; Hills et al. 1959) and animals (Walser, 1961; Massry et al. 1967). However, up to the early $1980 \mathrm{~s} \mathrm{Na}$ was not included among dietary factors believed to influence $\mathrm{Ca}$ requirements or the pathogenesis of osteoporosis (Draper \& Bell, 1979; Heaney et al. 1982; Spencer et al. 1982). Recently, there has been a renewal of interest in the calciuric effect of $\mathrm{Na}$ ingestion and it has been suggested that $\mathrm{Na}$ intake may be a contributory risk factor in the development of osteoporosis in certain individuals (Schaafsma et al. 1987; Heaney, 1988; Lindsay, 1988).

The present review examines the effect of dietary $\mathrm{Na}$ on $\mathrm{Ca}$ metabolism in man and animals and assesses the evidence for an association of high $\mathrm{Na}$ intakes with increased $\mathrm{Ca}$ requirements and increased bone resorption. It also attempts to identify areas in which further investigation would help to clarify the possible significance of this relationship in the development of osteoporosis.

- Present address: Rowett Research Institute, Bucksburn, Aberdeen AB2 9SB.

† For reprints. 
Table 1. Reabsorption sites for calcium and sodium in the rat kidney*

\begin{tabular}{lcc}
\hline \hline & \multicolumn{2}{c}{ Percentage reabsorbed } \\
\cline { 2 - 3 } Site & $\mathrm{Ca}$ & $\mathrm{Na}$ \\
\hline Proximal convoluted tubule & 40 & 45 \\
Loop of Henle & 45 & 43 \\
Distal convoluted tubule & 9 & 6 \\
Collecting ducts & 5 & 5 \\
\hline \hline
\end{tabular}

* Adapted from Suki (1979).

\section{PHYSIOLOGICAL BASIS FOR THE RELATIONSHIP BETWEEN URINARY SODIUM AND CALCIUM}

Most studies on the physiological basis for the relationship between urinary $\mathrm{Na}$ and $\mathrm{Ca}$ have been carried out on experimental animals, including the rat and dog, with few studies on humans.

Since there is no evidence for tubular secretion of either $\mathrm{Ca}$ or $\mathrm{Na}$ in the nephron (Sutton \& Dirks, 1977), the primary determinant of renal excretion is glomerular filtration of the ions. The major proportion of both plasma $\mathrm{Na}$ and $\mathrm{Ca}$ appears to be filtered and urinary excretion of $\mathrm{Na}$ and $\mathrm{Ca}$ is controlled by the extent of reabsorption of these ions from the nephron. Normally, $>99 \%$ of filtered $\mathrm{Na}$ and $>95 \%$ of filtered $\mathrm{Ca}$ is reabsorbed (Suki, 1979). In quantitative terms, the location of the reabsorption sites is similar for both ions (Table 1).

The dependence of urinary $\mathrm{Ca}$ excretion on urinary $\mathrm{Na}$ excretion has been attributed to the existence of linked or common reabsorption pathways for the ions in the convoluted portion of the proximal tubule and in the loop of Henle (Antoniou et al. 1969; McCarron et al. 1981). In contrast, there is no evidence for a similar relationship in the distal tubule or collecting ducts (Antoniou et al. 1969). Such conclusions are derived from studies using stop-flow and micropuncture techniques (Howard et al. 1959; Edwards et al. 1973; Agus et al. 1977) and from experimental observations into the effects of diuretics acting at different sites on the nephron (Parfitt, 1969; Costanzo \& Weiner, 1976; Sutton \& Dirks, 1977). For example, the loop diuretic, frusemide, which inhibits $\mathrm{Na}$ reabsorption in the thick ascending limb of the loop of Henle also inhibits the reabsorption of $\mathrm{Ca}$, suggesting a common reabsorption mechanism at this site (Sutton \& Dirks, 1977). In contrast, thiazide diuretics such as chlorothiazide, which inhibit distal tubular $\mathrm{Na}$ reabsorption actually lead to an increase in Ca transport at this site (Costanzo \& Windhager, 1978; Goulding \& Campbell, $1984 \mathrm{~b}$ ). Consequently, it has been concluded that $\mathrm{Na}$ and $\mathrm{Ca}$ are transported independently in the distal tubule (Suki, 1979). However, the actual mechanism by which $\mathrm{Na}$ influences $\mathrm{Ca}$ reabsorption in the proximal tubule is unknown (Suki, 1979).

\section{EFFECT OF SALT SUPPLEMENTATION ON CALCIUM METABOLISM IN THE RAT}

Numerous reports indicate that salt supplementation $(80 \mathrm{~g} / \mathrm{kg}$ diet $)$ significantly increases urinary $\mathrm{Ca}$ excretion in both intact and parathyroidectomized young rats (Goulding, $1980 a, b$; Goulding \& Campbell, 1984a; Shortt et al. 1987) and in adult intact rats (Goulding \& Campbell, 1983; Goulding \& Gold, 1986, 1988; Goulding \& McIntosh, 1986). Greger et al. (1987) also demonstrated that $\mathrm{Na}$ intake at a level $(8.4 \mathrm{~g} \mathrm{Na} / \mathrm{kg}$ diet equivalent 
to $21 \mathrm{~g} \mathrm{NaCl}$ ) lower than that used by Goulding and co-workers led to a significant increase in urinary $\mathrm{Ca}$ excretion in young rats (from 0.13 to $0.32 \mathrm{mg} / \mathrm{d}$ ). They found that the magnitude of calciuria was similar on days 8 and 20. The calciuric effect of salt supplementation $(80 \mathrm{~g} / \mathrm{kg}$ diet $)$ has been demonstrated to be sustained over $84 \mathrm{~d}$ in adult rats consuming a diet deficient in $\mathrm{Ca}(1 \mathrm{~g} / \mathrm{kg}$; Goulding \& Gold, 1986). However, Goulding \& Campbell (1983) found that the magnitude of the increment in urinary Ca excretion, induced by increased $\mathrm{Na}$ intake, decreased from $8.55 \mathrm{mg} / \mathrm{d}$ to $5.64 \mathrm{mg} / \mathrm{d}$ over an 8 -week period in rats fed on a diet which was very low in $\mathrm{Ca}(0 \cdot 1 \mathrm{~g} / \mathrm{kg})$, suggesting that the animals may adapt to the salt loads with time.

The literature is conflicting with regard to changes in $\mathrm{Ca}$ absorption during $\mathrm{NaCl}$ supplementation in rats. Goulding \& Campbell (1983) reported that adult oophorectomized rats consuming a low-Ca diet $(0.1 \mathrm{~g} / \mathrm{kg})$ for an 8 -week period exhibited no increase in net Ca absorption due to salt supplementation. Similarly, Goulding \& Campbell (1984a) demonstrated that net $\mathrm{Ca}$ absorption was not affected by salt supplementation in weanling rats receiving adequate dietary Ca with either a moderate $(250 \mathrm{~g} / \mathrm{kg})$ - or a high $(600 \mathrm{~g} / \mathrm{kg})$ protein diet. Goulding \& McIntosh (1986) found no change in net Ca-absorption during salt loading over a $10 \mathrm{~d}$ period in adult male rats fed on a low $(1 \mathrm{~g} / \mathrm{kg}) \mathrm{Ca}$ diet. In contrast, Goulding \& Gold (1986) reported increased net $\mathrm{Ca}$ absorption (68.7 v. $43.5 \%$ intake) in adult female rats consuming a low Ca diet $(1 \mathrm{~g} / \mathrm{kg})$ and salt supplement $(80 \mathrm{~g} / \mathrm{kg}$ diet) over a 3-month period compared to rats fed on the same diet without salt supplement. Salt supplementation reduced endogenous $\mathrm{Ca}$ loss but true $\mathrm{Ca}$ absorption was not reported. However, the increase in net $\mathrm{Ca}$ absorption was not sufficient to offset the increase in urinary $\mathrm{Ca}$ excretion induced by the salt supplements and $\mathrm{Ca}$ balance was lower in the saltsupplemented animals.

There is evidence that urinary hydroxyproline, an indicator of bone resorption, is significantly increased in rats given salt-supplemented diets (Goulding \& Campbell, 1983; Goulding \& Gold, 1986, 1988). Goulding \& Gold (1988) suggested that such increases in urinary hydroxyproline during salt supplementation were mediated by parathyroid hormone (PTH), since PTH is the major determinant of bone resorption rate. This is supported by the finding that parathyroidectomy abolishes the ability of salt to elevate urinary hydroxyproline (Goulding, 1980 b).

Since PTH increases excretion of urinary cAMP in the process of stimulating adenylate cyclase (EC 4.6.1.1) in the renal tubules (Garel, 1987), urinary cAMP is considered to be a sensitive index of parathyroid function. Urinary cAMP has been shown to be significantly elevated in animals given salt supplements $(80 \mathrm{~g} / \mathrm{kg}$ diet) compared with control animals (Goulding, 1980 b; Goulding \& Campbell, 1983, 1984a; Goulding \& McIntosh, 1986; Goulding \& Gold, 1986, 1988). Thus, Goulding \& Gold (1988) have suggested that the rise in urinary cAMP excretion observed during salt supplementation is indicative of increased PTH activity. This is supported by the finding that salt supplementation does not lead to an increase in urinary cAMP excretion in parathyroidectomized rats (Goulding, $1980 \mathrm{~b}$ ).

Goulding $(1980 b)$ reported that urinary cAMP failed to increase in young rats fed on a diet containing $0.1 \mathrm{~g} \mathrm{Ca} / \mathrm{kg}$ and salt supplements $(80 \mathrm{~g} / \mathrm{kg}$ diet $)$ for $84 \mathrm{~d}$ and suggested that maximal stimulation of PTH-mediated cAMP excretion had possibly already been caused by the low-Ca diet. Similarly, urinary cAMP was not increased by salt supplements $(80 \mathrm{~g} / \mathrm{kg}$ diet $)$ in young rats given a high-protein diet $(600 \mathrm{~g} / \mathrm{kg})$ containing $6 \mathrm{~g} \mathrm{Ca} / \mathrm{kg} \mathrm{diet}$ and salt for $14 \mathrm{~d}$ (Goulding \& Campbell, 1984a). The lack of an effect of salt supplementation on urinary cAMP in this study may be due to the high urinary cAMP excretion in the control group, which obscured any further increase that occurred due to salt supplementation.

Short-term (10-84 d) administration of dietary salt supplements ( $80 \mathrm{~g} / \mathrm{kg}$ diet $)$ have been 
reported to reduce significantly bone mass and bone $\mathrm{Ca}$ and phosphorus content in rats consuming diets containing dietary $\mathrm{Ca}$ at concentrations of $0 \cdot 1 \mathrm{~g} / \mathrm{kg}$ (Goulding, 1980 b; Goulding \& Campbell, 1982, 1983), $1 \mathrm{~g} / \mathrm{kg}$ (Goulding, 1980 $a$; Goulding \& Gold, 1986) or $6 \mathrm{~g} / \mathrm{kg}$ (Goulding \& Campbell, $1984 \mathrm{a}$; Shortt et al. 1987). However, Goulding (1980 $\mathrm{b}$ ) failed to show a significant effect of salt supplementation $(80 \mathrm{~g} / \mathrm{kg}$ diet $)$ on bone variables in young rats given diets containing $1 \mathrm{~g} \mathrm{Ca} / \mathrm{kg}$ for 16 or $84 \mathrm{~d}$. Similarly, Goulding \& Gold (1988) found that femur composition was similar in control and salt-supplemented $(80 \mathrm{~g} / \mathrm{kg} \mathrm{diet}$ ) adult female rats who were fed on a diet containing $1 \mathrm{~g} \mathrm{Ca} / \mathrm{kg}$ for $10 \mathrm{~d}$. They suggested that the absence of an effect of salt supplements was due to the short duration of the study. Greger et al. (1987) reported a significant reduction in tibia magnesium concentration, but not in tibia $\mathrm{Ca}$ or $\mathrm{P}$ concentrations (expressed per $\mathrm{g}$ ) in rats given a high$\mathrm{Na}$ diet $(8.4 \mathrm{~g} \mathrm{Na} / \mathrm{kg}$ diet equivalent to $21 \mathrm{~g} \mathrm{NaCl})$ containing adequate dietary $\mathrm{Ca}$ $(5 \mathrm{~g} / \mathrm{kg})$, compared with controls. However, as values per bone were not reported, it is not clear whether or not bone loss occurred.

The reduced bone mass of rats fed on salt-supplemented diets has been attributed to an increase in bone resorption rather than to a decrease in bone accretion. This has been demonstrated in studies examining the release of ${ }^{45} \mathrm{Ca}$ from labelled skeletons (Goulding \& Gold, 1986) and the uptake of $\left[{ }^{3} \mathrm{H}\right]$ hydroxyproline and ${ }^{45} \mathrm{Ca}$ into bone (Goulding \& Gold, 1988).

Thus, there is considerable evidence that salt supplementation reduces bone mass, $\mathrm{Ca}$ and $\mathrm{P}$ in young and adult rats. This appears to be due to $\mathrm{Na}$-induced calciuria which is not compensated for by increased $\mathrm{Ca}$ absorption or reduced endogenous loss and leads to PTH-mediated bone resorption.

However, most of the studies on the effects of salt on Ca metabolism in rats have been of relatively short duration (10-84 d) and the level of salt loading used (usually $80 \mathrm{~g} / \mathrm{kg}$ ) has been extremely high compared with the levels of dietary $\mathrm{Na}(0.5 \mathrm{~g} / \mathrm{kg}$ diet $)$ and chloride $(0.5 \mathrm{~g} / \mathrm{kg}$ diet $)$ recommended for the rat (National Research Council, 1978). Thus, there is a need for longer-term studies on the effect of dietary salt on bone employing lower dietary concentrations of salt.

While studies with rats have been useful in illustrating a number of aspects of the $\mathrm{Na}-\mathrm{Ca}$ relationship it is important to note that there are considerable differences in bone metabolism between rodents and humans. Draper (1985a) reported that rodents and humans differ with respect to the pattern of bone loss due to aging. In addition, rodents lack lamellar bone and consequently have a limited capacity for bone remodelling. Rodents also appear to be more susceptible than humans to the influence of dietary factors which increase the rate of bone resorption, e.g. protein and phosphorus (Draper, 1985 b). Since a much lower percentage of ingested $\mathrm{Ca}$ is excreted in urine in rats (approximately $1 \%, \mathrm{Bar}$, 1987) than in man (approximately 16\%, Schaafsma, 1983) and as $\mathrm{Na}$ exerts its effect on $\mathrm{Ca}$ primarily at the renal level, the rat may not be the most appropriate animal model for the study of $\mathrm{Na}-\mathrm{Ca}$ interactions. Furthermore, the renal concentrating capacity of the rat is about twice that of humans when expressed on a body-weight basis. Thus, studies on rats must be interpreted carefully, especially when extrapolating the results to human subjects.

\section{RELATIONSHIP BETWEEN URINARY SODIUM AND CALCIUM EXCRETION IN MAN}

\section{STUDIES ON FREE-LIVING INDIVIDUALS}

There is considerable evidence supporting a strong positive association between urinary $\mathrm{Na}$ and $\mathrm{Ca}$ excretion in both young and adult free-living individuals of both sexes consuming 
Table 2. Estimates of the incremental increase in urinary calcium excretion observed with $100 \mathrm{mmol}$ increment in urinary sodium excretion in free-living individuals consuming their usual diets

\begin{tabular}{|c|c|c|c|c|}
\hline \multirow[b]{2}{*}{ Reference } & \multicolumn{3}{|c|}{ Subjects } & \multirow{2}{*}{$\begin{array}{l}\text { Estimated increase } \\
\text { in urinary } \mathrm{Ca} \\
(\mathrm{mg}) / 100 \mathrm{mmol} \text { rise } \\
\text { in urinary } \mathrm{Na}\end{array}$} \\
\hline & Sex & $n$ & Age (years) & \\
\hline Modlin (1967) & $\begin{array}{l}\mathrm{M} / \mathrm{F} \\
\mathrm{M} / \mathrm{F}\end{array}$ & $\begin{array}{l}46 \\
50\end{array}$ & $\begin{array}{l}\text { Adult (Whites) } \\
\text { Adult (Bantu) }\end{array}$ & $\begin{array}{l}96 \\
12\end{array}$ \\
\hline McCarron et al. (1980) & $\mathbf{M} / \mathbf{F}$ & 34 & $43-47$ & 54 \\
\hline \multirow[t]{2}{*}{ Madden et al. (1983) } & $M$ & 25 & $19-21$ & 63 \\
\hline & $\mathbf{F}$ & 26 & $19-21$ & 106 \\
\hline \multirow{2}{*}{ Goulding et al. (1986) } & $\mathbf{M}$ & 484 & $20-69$ & 60 \\
\hline & $\mathbf{F}$ & 491 & $20-69$ & 52 \\
\hline \multirow{3}{*}{$\begin{array}{l}\text { Nordin \& Polley (1987) } \\
\text { Shortt et al. (1988) }\end{array}$} & $\mathbf{F}$ & 467 & Post-menopausal & 52 \\
\hline & $\mathbf{M}$ & 46 & $19-60$ & 91 \\
\hline & $\mathbf{F}$ & 48 & 1960 & 61 \\
\hline
\end{tabular}

their usual diet (Modlin, 1967; Dale, 1968; Goulding, 1981 ; Madden et al. 1983 ; Goulding et al. 1986; Nordin \& Polley, 1987; Law et al. 1988; Shortt et al. 1988). Goulding (1981) found that the urinary $\mathrm{Ca}$ :creatinine ratio was positively correlated with the urinary $\mathrm{Na}$ : creatinine ratio in fasting spot urine samples obtained from a group of 580 women (aged 16-82 years) during a health survey in New Zealand. Similarly, Law et al. (1988) found a significant positive correlation between the $\mathrm{Ca}$ :creatinine and $\mathrm{Na}$ :creatinine ratios in fasting spot urine samples of 99 male and 105 female Chinese. Furthermore, $24 \mathrm{~h}$ urinary $\mathrm{Ca}$ and $\mathrm{Na}$ excretion were positively correlated in every decade age-group studied during a health survey of 975 individuals in New Zealand (Goulding et al. 1986) and in 467 postmenopausal women in Australia (Nordin \& Polley, 1987).

Results from studies on free-living individuals suggest that the average increase in urinary $\mathrm{Ca}$ excretion per $100 \mathrm{mmol}$ increment in urinary $\mathrm{Na}$ in healthy individuals consuming their usual diet is in the range $12-106 \mathrm{mg}$ (Table 2), indicating considerable variation between groups examined. For example, in the study of Modlin (1967), white South Africans excreted, on average, $96 \mathrm{mg} \mathrm{Ca} / 100 \mathrm{mmol} \mathrm{Na}$ while Bantu excreted only $12 \mathrm{mg} \mathrm{Ca} / 100 \mathrm{mmol} \mathrm{Na}$. Such variation may indicate genetic differences in $\mathrm{Na}$ sensitivity but could also be due to dietary differences.

Few studies have controlled for the known calciuric effects of factors such as dietary $\mathrm{Ca}$, protein, caffeine or P, or acid-base status (Lemann et al. 1979; Heaney \& Recker, 1982; Massey \& Wise, 1984) or for the possible calciuric effects of non-dietary factors such as diuretics, antacids or antibiotics (Spencer \& Kramer, 1986). Madden et al. (1983), who observed a significant positive relationship between $24 \mathrm{~h}$ urinary excretion of $\mathrm{Na}$ and $\mathrm{Ca}$ in fifty-one young adults consuming their usual diet, found that $24 \mathrm{~h}$ urinary $\mathrm{Ca}$ or $\mathrm{Na}$ excretion were not significantly correlated with dietary $\mathrm{Ca}$, protein, $\mathrm{P}$ or fibre intakes. Nordin \& Polley (1987) found a significant positive association between urinary $\mathrm{Na}$ and $\mathrm{Ca}$ excretion for a group of post-menopausal women ( $n 445)$, but no significant association was observed for those individuals $(n$ 174) who consumed diets containing $>1000 \mathrm{mg} \mathrm{Ca} / \mathrm{d}$. Future studies which examine the relationship between urinary $\mathrm{Na}$ and $\mathrm{Ca}$ excretion in freeliving individuals should attempt to control for such confounding variables. 


\section{STUDIES WITH CONTROLLED SODIUM INTAKE}

In an early study it was noted that $\mathrm{NaCl}$ supplementation of two subjects with $30 \mathrm{~g} \mathrm{NaCl} / \mathrm{d}$ for $3 \mathrm{~d}$ increased urinary $\mathrm{Ca}$ excretion (Aub et al. 1937). Since then, a number of short-term studies have shown that acute increases in dietary $\mathrm{Na}$ intake generally cause an increase in urinary Ca excretion in healthy subjects. King et al. (1964) increased the dietary Na intake of eleven young adults from 20 to $160 \mathrm{mmol} / \mathrm{d}$ while maintaining a constant $\mathrm{Ca}$ intake $(2.0 \mathrm{~g} / \mathrm{d})$. They observed that the increase in $\mathrm{Na}$ intake was accompanied by an increase in urinary Ca excretion in some individuals. Similarly, Kleeman et al. (1964) varied the Na intake of six adults, who were consuming a near-constant Ca diet, from 20 to $425 \mathrm{mmol} / \mathrm{d}$, and found that $\mathrm{Ca}$ excretion increased as dietary $\mathrm{Na}$ intake was increased. Goulding $e t$ al. (1986) increased the $\mathrm{NaCl}$ intake of six young women, who were consuming a low- $\mathrm{Na}$ diet $(70 \mathrm{mmol} / \mathrm{d})$, by 50,100 and $150 \mathrm{mmol} / \mathrm{d}$ and reported that urinary $\mathrm{Ca}$ excretion, measured after $4 \mathrm{~d}$ on the supplements, increased by an average of 32,60 , and $72 \mathrm{mg} / \mathrm{d}$ respectively. Recently, McParland et al. (1989) reported that urinary Ca increased by an average of $23 \mathrm{mg} / \mathrm{d}$ in ten healthy post-menopausal women when given salt supplements $(100 \mathrm{mmol} / \mathrm{d})$ with a low-Na diet.

McCarron et al. (1981) varied the dietary $\mathrm{Na}$ intake of six adult males, who were consuming a fixed diet containing $400 \mathrm{mg}$ calcium/d, from 10 to $1500 \mathrm{mmol} / \mathrm{d}$. They found that mean urinary $\mathrm{Ca}$ excretion increased with progressive $\mathrm{Na}$ loading and attained an average maximum of $262 \mathrm{mg} / \mathrm{d}$ at $1500 \mathrm{mmol} \mathrm{Na} / \mathrm{d}$. Within the normal physiological range of $\mathrm{Na}$ intake (10-300 mmol/d) a linear relationship was observed between urinary $\mathrm{Na}$ and $\mathrm{Ca}$ excretion. Urinary $\mathrm{Ca}$ increased by $28 \mathrm{mg} / \mathrm{d}$, on average, for each $100 \mathrm{mmol}$ increment in dietary $\mathrm{Na}$ intake. However, a non-linear relationship was observed over the entire range of $\mathrm{Na}$ intakes examined $(10-1500 \mathrm{mmol} / \mathrm{d})$. Urinary $\mathrm{Ca}$ excretion $\left(\mathrm{U}_{\mathrm{Ca}}\right)$ increased in proportion to increases in the natural logarithm of urinary $\mathrm{Na}\left(\mathrm{U}_{\mathrm{Na}}\right)$ :

$$
\mathrm{U}_{\mathrm{Ca}}(\mathrm{mg} / \mathrm{d})=-69+40 \ln \mathrm{U}_{\mathrm{Na}}(\mathrm{mmol} / \mathrm{d}) \text {. }
$$

This study defined the limits of $\mathrm{Ca}$ excretion at extremes of $\mathrm{Na}$ intake and indicated that the linear relationship between urinary $\mathrm{Na}$ and $\mathrm{Ca}$ excretion, which is evident within the normal physiological range of $\mathrm{Na}$ intakes, is not maintained when $\mathrm{Na}$ intake is increased beyond the normal physiological limits.

$\mathrm{Na}$-induced increases in urinary $\mathrm{Ca}$ excretion have been demonstrated in individuals on daily Ca intakes of $400 \mathrm{mg}$ (Breslau et al. 1982; Sabto et al. 1984), 700-900 mg (Meyer et al. 1976; Shortt et al. 1988; McParland et al. 1989) and >1000 mg (King et al. 1964; Castenmiller et al. 1985; Goulding et al. 1986; Nordin \& Polley, 1987).

The slopes of the relationship between urinary $\mathrm{Ca}$ and $\mathrm{Na}$ excretion obtained in different studies on healthy subjects are summarized in Table 3. Urinary $\mathrm{Ca}$ increased by an average of 22 to $107 \mathrm{mg}$ for a $100 \mathrm{mmol}$ increase in urinary $\mathrm{Na}$ excretion.

Few investigators have considered it important to allow adequate time for adaptation to the change in dietary salt intake. While changes in $\mathrm{Na}$ intake may not be fully reflected in urinary $\mathrm{Na}$ for up to $5 \mathrm{~d}$, with an average lag of 3-5 d (Hollenberg, 1980), many studies have been of very short duration (3-5 d). Furthermore, dietary $\mathrm{Ca}$ has been changed from the usual intake in many studies. This issue was addressed by Castenmiller et al. (1985) who found that increasing dietary $\mathrm{Na}$ intake by $150 \mathrm{mmol} / \mathrm{d}$ significantly increased urinary $\mathrm{Ca}$ excretion in twelve young male adults who were consuming diets with a Ca content similar to their usual diet (approximately $1 \cdot 5--2 \cdot 0 \mathrm{~g} / \mathrm{d}$ ).

Several workers have demonstrated that hypercalciuric individuals may maintain $\mathrm{Ca}$ excretion in the normocalciuric range by simply restricting $\mathrm{Na}$ intake (Phillips \& Cooke 1967; Muldowney et al. 1982; Silver et al. 1983). Muldowney et al. (1982) reported that 
Table 3. Estimates of the incremental increase in urinary calcium observed in healthy individuals with a direct increase in urinary sodium excretion of $100 \mathrm{mmol} / \mathrm{d}$ during experimental studies

\begin{tabular}{|c|c|c|c|c|c|}
\hline \multirow[b]{2}{*}{ Reference } & \multicolumn{3}{|c|}{ Subjects } & \multirow{2}{*}{$\begin{array}{l}\text { Estimated increase } \\
\text { in urinary } \mathrm{Ca} \\
(\mathrm{mg}) / 100 \mathrm{mmol} \text { rise } \\
\text { in urinary } \mathrm{Na}\end{array}$} & \multirow[b]{2}{*}{$\begin{array}{l}\text { Dietary } \\
\text { Ca (mg) }\end{array}$} \\
\hline & Sex & $n$ & $\begin{array}{c}\text { Age } \\
\text { (years) }\end{array}$ & & \\
\hline Phillips \& Cooke (1967) & $\mathbf{M}$ & 10 & $25-38$ & 107 & 750 \\
\hline Phillips \& Cooke (1967) & $\mathbf{M}$ & 10 & $25-38$ & 55 & $<200$ \\
\hline Meyer et al. (1976) & $M / F$ & 2 & Adult & 24 & 786 \\
\hline McCarron et al. (1981) & $\mathbf{M}$ & 6 & $18-40$ & 28 & 400 \\
\hline \multirow[t]{2}{*}{ Breslau et al. (1982) } & $\mathbf{M}$ & 6 & $22-36$ & 26 & 400 \\
\hline & $\mathbf{F}$ & 5 & & & \\
\hline \multirow[t]{2}{*}{ Sabto et al. (1984) } & $\mathbf{M}$ & 18 & $25-39$ & 60 & 400 \\
\hline & $\mathrm{F}$ & 20 & & & \\
\hline Castenmiller et al. (1985) & $\mathbf{M}$ & 12 & $19-26$ & 22 & 1800 \\
\hline Goulding et al. (1986) & $\mathrm{F}$ & 6 & $19-23$ & 63 & - \\
\hline \multirow[t]{2}{*}{ Shortt et al. (1988) } & $\mathbf{M}$ & 6 & 21.25 & 35 & 700 \\
\hline & $\mathbf{F}$ & 6 & 21.25 & 28 & 700 \\
\hline Law et al. (1988) & $\mathbf{M}$ & 4 & 30 & 60 & - \\
\hline McParland et al. (1989) & $\mathrm{F}$ & 10 & 67 & 23 & 850 \\
\hline
\end{tabular}

when the $\mathrm{Na}$ intake of eighteen hypercalciuric subjects was reduced to approximately $80 \mathrm{mmol} / \mathrm{d}$, urinary $\mathrm{Ca}$ was reduced to $278 \mathrm{mg} / \mathrm{d}$ on average. Subsequently, when the $\mathrm{Na}$ intake of these subjects was increased to $200 \mathrm{mmol} / \mathrm{d}$ for a further $7 \mathrm{~d}$, urinary Ca excretion increased to $384 \mathrm{mg} / \mathrm{d}$. Similarly, Silver et al. (1983) reported that moderate Na restriction (to less than $150 \mathrm{mmol} / \mathrm{d}$ ) corrected hypercalciuria in four patients. Muldowney et al. (1982) suggested that idiopathic hypercalciuria may be provoked by a high $\mathrm{Na}$ intake and that Na restriction may be a valuable mode of therapy. Phillips \& Cooke (1967) reported that hypercalciuric patients, as a group, excreted $140 \mathrm{mg} \mathrm{Ca} / 100 \mathrm{mmol} \mathrm{Na}$ increment, while normocalciuric patients excreted, on average, $107 \mathrm{mg} \mathrm{Ca} / 100 \mathrm{mmol} \mathrm{Na}$ increment on similar, fixed diets.

\section{MAGNITUDE OF SODIUM-INDUCED CALCIURIA}

The magnitude of the calciuria elicited by increases in dietary Na intake is comparable with the calciuric effects of dietary constituents such as protein and caffeine (Heaney \& Recker, 1982; Heaney, 1988; Lindsay, 1988). Schaafsma et al. (1987) calculated that increasing the protein content of the diet from natural sources by $20 \mathrm{~g} / \mathrm{d}$ results in an increase in urinary $\mathrm{Ca}$ of $20 \mathrm{mg} / \mathrm{d}$ and that an increase of $150 \mathrm{mg}$ caffeine/d (equivalent to two cups of coffee) increases urinary $\mathrm{Ca}$ by $5 \mathrm{mg} / \mathrm{d}$. In comparison, studies on free-living subjects consuming their usual diet (Table 2) indicate that an increase in dietary $\mathrm{Na}$ intake of $100 \mathrm{mmol}$ results in an average increase in urinary $\mathrm{Ca}$ excretion of 12-106 mg. Similarly, direct increases in urinary $\mathrm{Na}$ excretion have been shown to increase urinary $\mathrm{Ca}$ excretion on average by $22-107 \mathrm{mg} / 100 \mathrm{mmol} \mathrm{Na}$ in healthy subjects (Table 3). Considering the reported range of urinary $\mathrm{Na}$ excretion (and hence $\mathrm{Na}$ intake) in human populations $(0.2-242 \mathrm{mmol} / \mathrm{d}$, Intersalt Cooperative Research Group, 1988), the possible influence of dietary Na intake on urinary $\mathrm{Ca}$ loss may be considerable.

Thus, $\mathrm{Na}$ intake appears to be a major determinant of urinary $\mathrm{Ca}$ excretion. However, no studies have systematically investigated whether the calciuric effect of dietary $\mathrm{Na}$ intake 

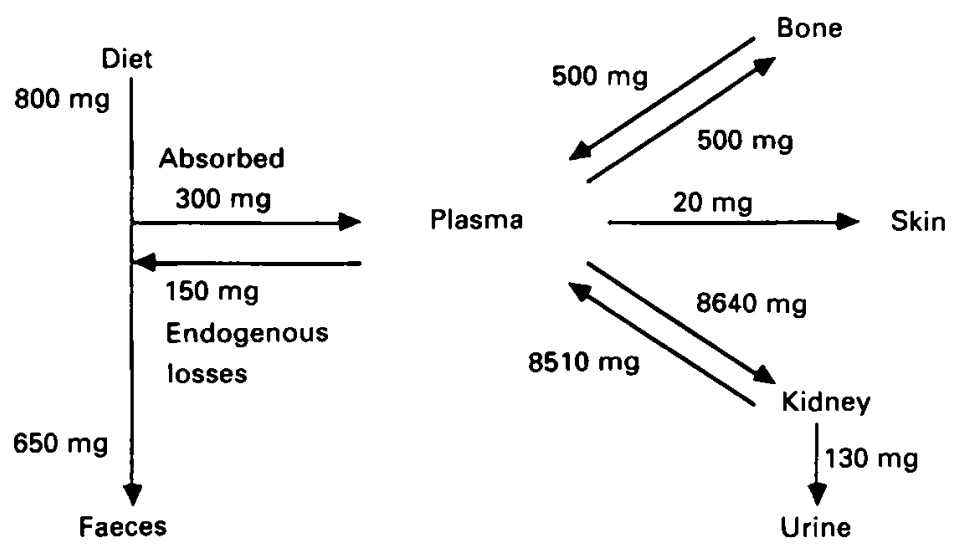

Fig. 1. Schematic representation of daily calcium turnover under balance conditions. Adapted from Schaafsma (1983).

is influenced by other dietary factors (e.g. protein, $\mathrm{Ca}, \mathrm{P}$ ) which are known also to affect urinary $\mathrm{Ca}$ excretion.

\section{INDIVIDUAL VARIABILITY IN URINARY CALCIUM RESPONSE TO DIETARY SODIUM INTAKE}

King et al. (1964) reported that, of eleven subjects given diets supplemented with $130 \mathrm{mmol} \mathrm{Na} / \mathrm{d}$, urinary $\mathrm{Ca}$ excretion increased in five, remained unchanged in four and decreased in two subjects. Since then many studies have demonstrated that there is considerable variation between healthy individuals in their calciuric response to increasing $\mathrm{NaCl}$ intake (Kleeman et al. 1964; Meyer et al. 1976; McCarron et al. 1981; Castenmiller et al. 1985; Shortt et al. 1988). Meyer et al. (1976) observed that, following an increase in $\mathrm{Na}$ intake (from 10 to $250 \mathrm{mmol} / \mathrm{d}$ ) by ten subjects, urinary Ca excretion increased in five, decreased in three and showed no significant change in two subjects. Similarly, Castenmiller et al. (1985) reported that individual responses to an increase in dietary $\mathrm{Na}$ intake varied considerably among free-living young males. The urinary $\mathrm{Ca}$ :creatinine ratio increased for nine, remained virtually unchanged for two and decreased for one subject. Shortt et al. (1988) were unable to detect a relationship between $\mathrm{Na}$ intake (varied from 40 to $220 \mathrm{mmol} /$ day) and urinary $\mathrm{Ca}$ excretion in seven of twelve young adults studied. For subjects in whom a positive correlation was found, the slopes of the regression lines ranged from 30 to $113 \mathrm{mg} \mathrm{Ca} / 100 \mathrm{mmol} \mathrm{Na}$. This suggests that, while some individuals show a strong relationship between $\mathrm{Na}$ intake and urinary $\mathrm{Ca}$ excretion, the relationship may be more difficult to detect or may not exist in others. The basis for this inter-individual variability in $\mathrm{Na}$ sensitivity has not been investigated.

\section{EFFECT OF SODIUM INTAKE ON SERUM PARATHYROID HORMONE, CALCIUM ABSORPTION AND BALANCE}

While there is little doubt that increasing salt intake increases urinary $\mathrm{Ca}$ excretion in many, although not all, humans this phenomenon is of little significance if there is complete adaptation, i.e. if net $\mathrm{Ca}$ absorption is increased by an amount sufficient to offset the increased urinary loss (see Fig. 1). 


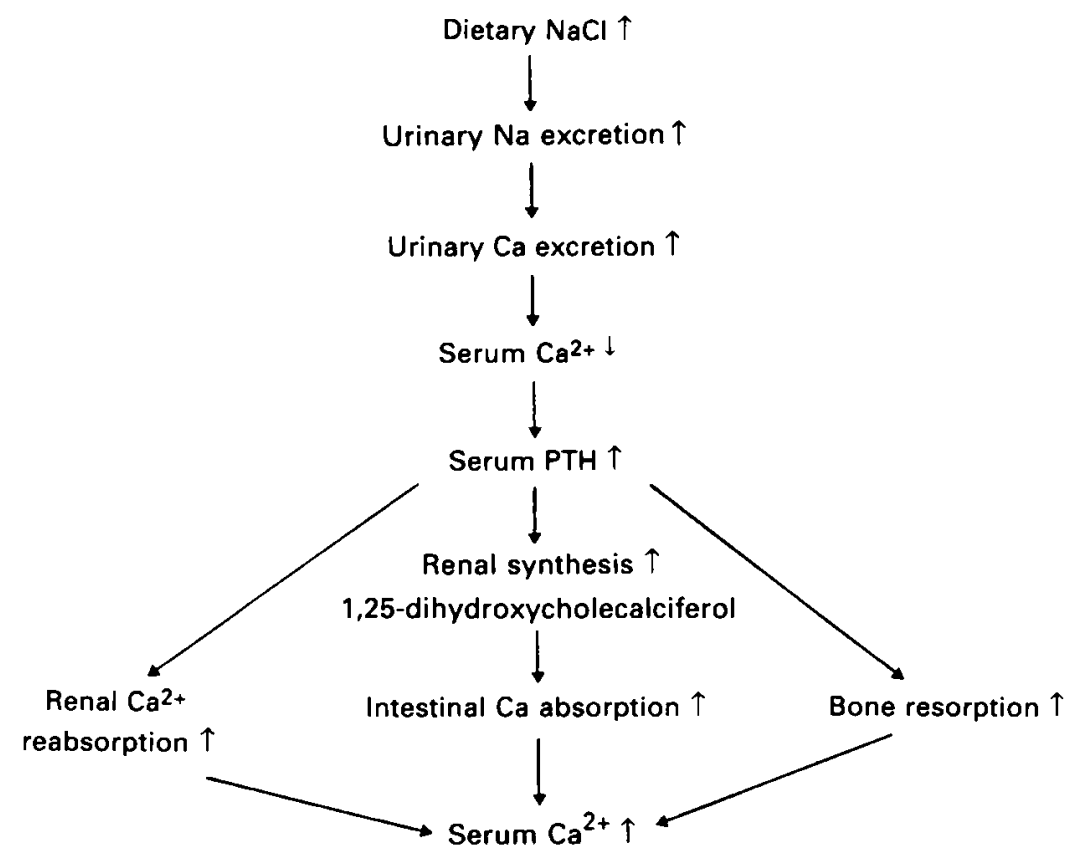

Fig. 2. Effects of increasing dietary sodium chloride on calcium metabolism. Adapted from Goulding et al. (1986). PTH, parathyroid hormone.

Under normal conditions, an equilibrium exists between ionized $\mathrm{Ca}$ and PTH in serum. It has been suggested that $\mathrm{Na}$-induced calciuria temporarily depresses serum ionized $\mathrm{Ca}$ concentration which, in turn, stimulates the release of PTH (Fig. 2). PTH then acts on the kidney, intestine (via renal 1,25-dihydroxycholecalciferol synthesis) and bone to restore serum ionized $\mathrm{Ca}$ to normal levels (Goulding et al. 1986).

Serum PTH has been found to be significantly increased in association with $\mathrm{Na}$-induced calciuria when the level of $\mathrm{Na}$ supplementation was within the normal physiological range (10-300 mmol/d) of $\mathrm{Na}$ intakes (Coe et al. 1975; McCarron et al. 1981; Breslau et al. 1982; Zemel et al. 1986). However, despite similarity in study design (subjects and $\mathrm{Na}$ loads), the observed increment in serum PTH with the imposition of the high-Na diets differed considerably among studies (Coe et al. 1975; McCarron et al. 1981; Breslau et al. 1982). Interpretation of studies which examine PTH changes are made difficult by differences in sensitivity of the radioimmunoassays used, the pulsatile nature of serum PTH concentrations, and the possible haemodilution effect of $\mathrm{Na}$ loading (Slatopolsky et al. 1982; Garel, 1987; Jubiz et al. 1972; Magliaro, 1983).

$\mathrm{Ca}$ absorption has been reported to increase in response to dietary Na intake (Meyer et al. 1976; Breslau et al. 1982). Meyer et al. (1976) observed that $\mathrm{Ca}$ absorption, as measured by ${ }^{47} \mathrm{Ca}$ uptake from calcium chloride increased by $8 \%$ on average in ten patients, including eight with normal parathyroid function and two with post-surgical hypoparathyroid function who were changed from a low-Na $(10 \mathrm{mmol} / \mathrm{d})$ to a high- $\mathrm{Na} \operatorname{diet}(250 \mathrm{mmol} / \mathrm{d})$ for $12 \mathrm{~d}$. On an individual basis, $\mathrm{Ca}$ absorption increased in six of the eight subjects with normal parathyroid function and in the two with hypoparathyroid function. Using a similar study design, Breslau et al. (1982) increased the $\mathrm{Na}$ intake $(10-250 \mathrm{mmol} / \mathrm{d})$ of eleven healthy subjects (six male, five female, average age 27 years) for $10 \mathrm{~d}$ and found a 
significant increase in fractional intestinal Ca absorption from 0.39 to 0.49 as well as in serum 1,25-dihydroxycholecalciferol (from 38 to $51 \mathrm{pg} / \mathrm{ml}$ ). However, in contrast to the findings of Meyer et al. (1976), two patients with post-surgical hypoparathyroidism did not show similar increases. Breslau et al. (1982) explained the difference by suggesting that the patients in the earlier study were incorrectly diagnosed as having hypoparathyroidism, since the subjects were normocalcaemic during the study due to vitamin $\mathrm{D}$ treatment. It was concluded that $\mathrm{Na}$-induced increases in $\mathrm{Ca}$ absorption were mediated by PTH.

However, Breslau et al. (1985) found no increase in intestinal Ca absorption in seven osteoporotic post-menopausal women maintained on a constant diet containing $10 \mathrm{mmol} \mathrm{Na}$ and $400 \mathrm{mg} \mathrm{Ca} / \mathrm{d}$ for $10 \mathrm{~d}$ when $\mathrm{Na}$ intake was increased to $250 \mathrm{mmol} / \mathrm{d}$ for a further $10 \mathrm{~d}$. Serum concentrations of 1,25-dihydroxycholecalciferol and PTH were also unchanged in response to the increase in $\mathrm{Na}$ intake. The authors concluded that postmenopausal women with osteoporosis have impaired adaptation of the parathyroidvitamin $\mathrm{D}$ axis and of intestinal $\mathrm{Ca}$ absorption to salt-induced urinary $\mathrm{Ca}$ loss which may result in negative $\mathrm{Ca}$ balance and contribute to the development of osteoporosis in these women.

McParland et al. (1989) reported that there was no increase in mean strontium absorption (an index of Ca absorption) in nine healthy post-menopausal women (mean age, 67 years) consuming low-salt diets when they were supplemented with $100 \mathrm{mmol} \mathrm{Na}$ daily for $10 \mathrm{~d}$. Urinary cAMP increased significantly for the group and also in each subject, indicating an increase in serum PTH. However, serum 1,25-dihydroxycholecalciferol showed a definite increase in only three subjects, remained largely unchanged in the other six and did not increase significantly for the group overall.

The effect of salt on $\mathrm{Ca}$ balance has received little study. While Goulding et al. (1986) have suggested that the daily $\mathrm{Ca}$ requirement to maintain $\mathrm{Ca}$ balance is higher in individuals consuming a high-Na diet than in individuals consuming a low- $\mathrm{Na}$ diet this has not been established in balance studies. Fujita et al. (1984) found that, despite a marked increase in urinary $\mathrm{Ca}$ excretion, $\mathrm{Ca}$ balance was not significantly affected in eight healthy subjects in response to oral salt loading $(100 \mathrm{mmol} / \mathrm{d})$ together with fruseniide administration $(80 \mathrm{mg} / \mathrm{d})$ for an $8 \mathrm{~d}$ period. They observed significant increases in mean serum PTH, and in mean nephrogenous and total cAMP excretion and a significant decrease in faecal Ca excretion ( 365 v. $294 \mathrm{mg} \mathrm{Ca} / \mathrm{d}$ ). These results suggest that calciuria was compensated for by increased $\mathrm{Ca}$ absorption mediated by increased serum PTH but reduced endogenous $\mathrm{Ca}$ loss could also have contributed. Indeed, the effect of salt loading on endogenous Ca secretion into the gastrointestinal tract (approximately $150 \mathrm{mg} / \mathrm{d}$ in human adults; Schaafsma, 1983) has not been studied.

Thus, the available evidence suggests that healthy individuals adapt to $\mathrm{Na}$-induced calciuria by a PTH-mediated increase in intestinal $\mathrm{Ca}$ absorption. However, this adaptive mechanism does not appear to function in all individuals (e.g. those with impaired parathyroid function, post-menopausal women with osteoporosis, as well as some healthy post-menopausal women) and even in those individuals who appear to adapt, the increase in net $\mathrm{Ca}$ absorption may not be sufficient to offset the increase in urinary Ca losses (Breslau et al. 1982). Furthermore, the capacity for such adaptation may be limited by low dietary $\mathrm{Ca}$ intakes, poor vitamin $\mathrm{D}$ status, impaired renal function or poor intestinal $\mathrm{Ca}$ absorption.

Thus, there is a need for further studies to clarify whether and in what circumstances Nainduced calciuria may lead to negative calcium balance. 


\section{EFFECT OF SODIUM INTAKE ON BONE METABOLISM AND OSTEOPOROSIS IN MAN}

The possible effects of a high dietary $\mathrm{Na}$ intake on bone metabolism have received little attention. To date, only two studies have investigated the effect of high $\mathrm{Na}$ intakes on bone mass in man.

Nordin \& Polley (1987) reported that forearm mineral density, corrected for age and years since menopause, was significantly and negatively correlated with $24 \mathrm{~h}$ urinary $\mathrm{Na}$ excretion in a cross-sectional study of $\mathbf{4 4 0}$ healthy post-menopausal women.

A 9-month intervention study examining the effect of moderate salt restriction (to $85 \mathrm{mmol} / \mathrm{d}$ ) on bone metabolism was carried out on thirty-four post-menopausal women consuming high-Ca (>1000 mg/d) diets (Nordin \& Polley, 1987). Salt restriction did not reduce the rate of bone loss, as assessed by the rate of change of forearm mineral density, which continued at a similar rate to that in matched controls $(n 60)$ on an unrestricted diet. The authors suggested that salt restriction might have been more effective in decreasing bone loss in women consuming a low-Ca diet. However, the salt restriction achieved in this study was less than intended, i.e. while a reduction in $24 \mathrm{~h}$ urinary $\mathrm{Na}$ excretion did occur in the salt-restricted group, mean $24 \mathrm{~h}$ urinary $\mathrm{Na}$ remained higher than $100 \mathrm{mmol}$ and the difference between the salt-restricted group and controls was only of the order of 20-30 mmol. Furthermore, compliance with salt restriction was assessed by only two $24 \mathrm{~h}$ urine samples over the entire 9-month intervention period.

There is considerable evidence that urinary hydroxyproline, which is a marker for bone resorption (Klein et al. 1964) is significantly and positively associated with $\mathrm{Na}$ intake. Goulding (1981) reported that the Na:creatinine ratio was positively correlated with the $\mathrm{Ca}$ :creatinine ratio and with the hydroxyproline:creatinine ratio in fasting urine samples obtained from 574 women aged $16-82$ years. Urinary $\mathrm{Na}$ :creatinine ratio was also positively correlated with urinary $\mathrm{Ca}$ :creatinine ratio and urinary hydroxyproline: creatinine ratio in a cross-sectional study of 546 healthy post-menopausal women (Nordin \& Polley, 1987). Similarly, positive associations have been found between urinary $\mathrm{Na}$ and urinary $\mathrm{Ca}$ and hydroxyproline excretion when dietary $\mathrm{Na}$ intake has been directly increased by $100 \mathrm{mmol} / \mathrm{d}$ in young women (Goulding \& Lim, 1983; Goulding et al. 1986). Moreover, the $\mathrm{Na}$-induced increase in $\mathrm{Ca}$ and hydroxyproline excretion was apparent irrespective of dietary Ca intake (200 $\mathrm{mg}$ or $1500 \mathrm{mg} \mathrm{Ca} / \mathrm{d}$; Goulding et al. 1986).

One reservation about the previously described studies is that dietary hydroxyproline was not controlled and dietary hydroxyproline may affect urinary hydroxyproline excretion (Sjoerdsma et al. 1965; Kivirikko, 1970). However, Goulding \& MacDonald (1986) found that $81 \%$ of the variation in urinary hydroxyproline was explained by the variation in urinary $\mathrm{Na}$ in a healthy 35 -year-old woman during one menstrual cycle while consuming a hydroxyproline-free diet, suggesting that increases in salt intake may increase bone resorption. Furthermore, McParland et al. (1989) reported increased urinary hydroxyproline excretion in nine healthy post-menopausal women consuming a low-salt diet when they were supplemented with $100 \mathrm{mmol} \mathrm{Na}$ for $10 \mathrm{~d}$ and gelatin was excluded from the diet.

In contrast, Castenmiller et al. (1985) reported that the Na-induced increase in urinary $\mathrm{Ca}$ excretion observed in young males while consuming diets containing $1.5-2.0 \mathrm{~g} \mathrm{Ca} / \mathrm{d}$ was not associated with an increase in urinary hydroxyproline excretion. They suggested that the extra $\mathrm{Ca}$ excreted was not derived from bone but may have been derived from increased absorption or by a decrease in endogenous loss. However, these variables were not measured. Goulding et al. (1986) have suggested that the lack of effect of $\mathrm{Na}$ on urinary hydroxyproline in the study of Castenmiller et al. (1985) may be due to the high passive 
absorption of dietary Ca which may have depressed the PTH-vitamin D axis. However, Goulding et al. (1986) found that urinary hydroxyproline was increased in young women despite a high $\mathrm{Ca}$ intake $(1.5 \mathrm{~g} / \mathrm{d})$.

In order to monitor the effects of dietary change on bone remodelling and to provide a more accurate assessment of bone status, future studies should measure a range of boneturnover markers. Several markers, in addition to urinary hydroxyproline, provide an indication of bone-turnover status, e.g. serum osteocalcin and alkaline phosphatase (EC 3.1.3.1) bone isoenzyme (indices of bone formation) and urinary hydroxylysine (index of bone resorption; Delmas, 1988; Taylor et al. 1988). For example, (McParland et al. 1989) reported that serum osteocalcin concentration was increased in healthy postmenopausal women supplemented with $100 \mathrm{mmol} \mathrm{Na} / \mathrm{d}$, indicating increased formation of bone.

\section{CONCLUSIONS}

Studies on rats have clearly shown that $\mathrm{Na}$-induced calciuria which is not compensated for by increased $\mathrm{Ca}$ absorption or reduced endogenous $\mathrm{Ca}$ loss leads to PTH-mediated bone resorption. However, very high levels of salt loading were used in these studies and the relevance of such studies to humans is unclear, particularly given the known differences in Ca metabolism between rodents and humans.

In man, $\mathrm{Na}$-induced calciuria has been clearly demonstrated in many studies and the magnitude of this effect within the usual range of $\mathrm{Na}$ intakes is significant in relation to overall Ca metabolism. There is also evidence of considerable inter-individual variation in the hypercalciuric effect of $\mathrm{Na}$ and the basis of this variation has not been investigated.

The available evidence suggests that healthy individuals adapt to $\mathrm{Na}$-induced calciuria by a PTH-mediated increase in intestinal $\mathrm{Ca}$ absorption. However, this adaptive mechanism does not appear to function in all individuals (e.g. those with impaired parathyroid function, post-menopausal women with osteoporosis, as well as some healthy postmenopausal women) and even in those individuals who appear to adapt, the increase in net $\mathrm{Ca}$ absorption may not be sufficient to offset the increase in urinary $\mathrm{Ca}$ losses. Furthermore, the capacity for such adaptation may be limited by low dietary Ca intakes, poor vitamin $\mathrm{D}$ status, impaired renal function or poor intestinal $\mathrm{Ca}$ absorption. The effect of salt loading on endogenous $\mathrm{Ca}$ secretion into the gastrointestinal tract or on overall Ca balance has not been investigated and there is a need for studies to clarify whether and in what circumstances $\mathrm{Na}$-induced calciuria may lead to negative $\mathrm{Ca}$ balance.

The possible effects of a high dietary $\mathrm{Na}$ intake on bone metabolism have received little attention. While there is evidence of an association between high salt intakes and increased bone resorption (as indicated by increased urinary hydroxyproline) it has not been established if this results in net bone loss. In the only longitudinal study of salt restriction on bone mass reported to date there was no evidence of an association of $\mathrm{Na}$ intake with bone mass.

Thus, the evidence for an association between $\mathrm{Na}$ intake and osteoporosis in man is not clear or strong enough at present to justify intervention at an individual or population level. However, there are still many unresolved questions regarding the $\mathrm{Na}-\mathrm{Ca}$ relationship and there is a need for more studies on the effect of salt on bone metabolism, particularly in post-menopausal women.

\section{REFERENCES}

Agus, Z. S., Chiu, P. J. S. \& Goldberg, M. (1977). Regulation of urinary calcium excretion in the rat. American Journal of Physiology 232, F545-F549.

Antoniou, L. D., Eisner, G. M., Slotkoff, L. M. \& Lilienfield, L. S. (1969). Relationship between sodium and calcium transport in the kidney. Journal of Laboratory and Clinical Medicine 74, 410-420. 
Aub, J. C., Tibbetts, D. M. \& McLean, R. (1937). The influence of parathyroid hormone, urea, sodium chloride, fat and of intestinal activity upon calcium balance. Journal of Nutrition 13, 635-655.

Bar, A. (1987). Toxicological aspects of sugar alcohols-studies with xylitol. In Low Digestibility Carbohydrates, pp. 42- 50 [D. C. Leegwater, V. J. Feron and R. J. J. Hermus, editors]. Wageningen: Pudoc Wageningen.

Breslau, N. A., McGuire, J. L., Zerwekh, J. E. \& Pak, C. Y. C. (1982). The role of dietary sodium on renal excretion and intestinal absorption of calcium and on vitamin D metabolism. Journal of Clinical Endocrinology and Metabolism 55, 369-373.

Breslau, N. A., Sakhaee, K. \& Pak, C. Y. C. (1985). Impaired adaptation to salt-induced urinary calcium losses in postmenopausal osteoporosis. Transactions of the Association of American Physicians 98, $107-115$.

Castenmiller, J. J. M., Mensink, R. P., Van der Heijden, L., Kouwenhoven, T., Hautvast, J. G. A. J., de Leeuw, P. W. \& Schaafsma, G. (1985). The effect of dietary sodium on urinary calcium and potassium excretion in normotensive men with different calcium intakes. American Journal of Clinical Nutrition 41, 52-60.

Coe, F. L., Firpo, J. J., Hollandsworth, D. L., Segil, L., Canterbury, J. M. \& Reiss, E. (1975). Effect of acute and chronic metabolic acidosis on serum immunoreactive parathyroid hormone in man. Kidney International 8 , 262-273.

Costanzo, L. S. \& Weiner, I. (1976). Relationship between clearances of Ca and Na: effect of distal diuretics and PTH. American Journal of Physiology 230, 67-73.

Costanzo, L. S. \& Windhager, E. E. (1978). Calcium and sodium transport by the distal convoluted tubule of the rat. American Journal of Physiology 235, F492-F506.

Dale, N. E. (1968). A study of the urinary calcium, phosphorus, creatinine and sodium excretion of young adults in Sydney. Medical Journal of Australia 2, 791-793.

Delmas, P. D. (1988). Biochemical markers of bone turnover in osteoporosis. In Osteoporosis : Etiology, Diagnosis, and Management, pp. 297-315 [B. L. Riggs and L. J. Melton, editors]. New York: Raven Press.

Draper, H. H. (1985a). Animal models for the study of nutrition and human disease: Colon cancer, atherosclerosis and osteoporosis. In Advances in Nutritional Research, vol. 7, Osteoporosis III, pp. 155-186 [H. H. Draper, editor]. New York: Plenum Press.

Draper, H. H. $(1985 \mathrm{~b})$. Similarities and differences in the responses of animals and man to factors affecting calcium needs. In Calcium in Biological Systems, pp. 575-581 [R. P. Rubin, G. B. Weiss and J. W. Putney, editors]. New York: Plenum Press.

Draper, H. H. \& Bell, R. R. (1979). Nutrition and osteoporosis. In Advances in Nutritional Research, vol. 2, pp. 79-106 [H. H. Draper, editor]. New York: Plenum Press.

Edwards, B. R., Baer, P. G., Sutton, R. A. L. \& Dirks, J. H. (1973). Micropuncture study of diuretic effects on sodium and calcium reabsorption in the dog nephron. Journal of Clinical Investigation 52, 2418-2427.

Fujita, T., Chan, J. C. M. \& Bartter, F. C. (1984). Effects of oral furosemide and salt loading on parathyroid function in normal subjects. Physiological basis for renal hypercalciuria. Nephron 38, 109-114.

Garel, J. M. (1987). Hormonal control of calcium metabolism during the reproductive cycle in mammals. Physiological Reviews 67, 1-66.

Goulding, A. $(1980 a)$. Effects of sodium chloride supplements on tibial calcium content in rats taking a lowcalcium diet with a moderate or a high protein intake. Proceedings of the University of Otago Medical School $58,13-14$.

Goulding, A. (1980 b). Effects of dietary $\mathrm{NaCl}$ supplements on parathyroid function, bone turnover and bone composition in rats taking restricted amounts of calcium. Mineral and Electrolyte Metabolism 4, $203-208$.

Goulding, A. (1981). Fasting urinary sodium/creatinine in relation to calcium/creatinine and hydroxyproline/creatinine in a general population of women. New Zealand Medical Journal 93, 294-297.

Goulding, A. \& Campbell, D. R. (1982). Generalized skeletal loss of calcium induced by oral sodium chloride supplements in adult oophorectomized rats consuming a low-calcium diet. Proceedings of the University of Otago Medical School 60, 3-4.

Goulding, A. \& Campbell, D. R. (1983). Dietary $\mathrm{NaCl}$ loads promote calciuria and bone loss in adult oophorectomized rats consuming a low calcium diet. Journal of Nutrition 113, 1409-1414.

Goulding, A. \& Campbell, D. R. (1984a). Effects of oral loads of sodium chloride on bone composition in growing rats consuming ample dietary calcium. Mineral and Electrolyte Metabolism 10, 58-62.

Goulding, A. \& Campbell, D. R. (1984b). Hypocalciuric effects of hydrochlorothiazide in the rat during $\mathrm{NaHCO}_{3}$, $\mathrm{NaCl}$, and $\mathrm{NH}_{4} \mathrm{Cl}$ loading. Renal Physiology 7, 185-191.

Goulding, A., Everitt, H. E., Cooney, J. M. \& Spears, G. F. S. (1986). Sodium and osteoporosis. In Recent Advances in Clinical Nutrition, vol. 2, pp. 99-108 [M. L. Wahlqvist and A. S. Truswell, editors]. London: John Libbey.

Goulding, A. \& Gold, E. (1986). Effects of dietary sodium chloride loading on parathyroid function, 1,25dihydroxyvitamin $\mathrm{D}$, calcium balance, and bone metabolism in female rats during chronic prednisolone administration. Endocrinology 119, 2148-2154.

Goulding, A. \& Gold, E. (1988). Effects of dietary $\mathrm{NaCl}$ supplementation on bone synthesis of hydroxyproline, urinary hydroxyproline excretion and bone ${ }^{45} \mathrm{Ca}$ uptake in the rat. Hormone and Metabolic Research 20. 743-745.

Goulding, A. \& Lim, P. E. (1983). Effects of varying dietary salt intake on the fasting urinary excretion of sodium, calcium and hydroxyproline in young women. New Zealand Medical Journal 96, 853-854. 
Goulding, A. \& McDonald, B. (1986). Intra-individual variability in fasting urinary calcium/creatinine and hydroxyproline/creatinine measurements. In Recent Advances in Clinical Nutrition, vol. 2, pp. 312-313. [M. L. Wahlquist and A. S. Truswell, editors]. London: John Libbey.

Goulding, A. \& McIntosh, J. (1986). Effects of $\mathrm{NaCl}$ on calcium balance, parathyroid function and hydroxyproline excretion in prednisolone-treated rats consuming low calcium diet. Journal of Nutrition 116, 1037-1044.

Greger, J. L., Krashoc, C. L. \& Krzykowski, C. E. (1987). Calcium, sodium and chloride interactions in rats. Nutrition Research 7, $401-412$.

Heaney, R. P. (1988). Nutritional factors in bone health. In Osteoporosis : Etiology, Diagnosis, and Management, pp. 359-372 [B. L. Riggs and L. J. Melton, editors]. New York: Raven Press.

Heaney, R. P., Gallagher, J. C., Johnston, C. C., Neer, R., Parfitt, A. M. \& Whedon, G. D. (1982). Calcium nutrition and bone health in the elderly. American Journal of Clinical Nutrition 36, 986-1013.

Heaney, R. P. \& Recker, R. R. (1982). Effects of nitrogen, phosphorus, and caffeine on calcium balance in women. Journal of Laboratory and Clinical Medicine 99, 46-55.

Hills, A., Parsons, D., Webster, G., Rosenthal, O. \& Conover, H. (1959). Influence of the renal excretion of sodium chloride upon the renal excretion of magnesium and other ions by human subjects. Journal of Clinical Endocrinology and Metabolism 19, 11921211.

Hollenberg, N. K. (1980). Set point for sodium homeostasis: surfeit, deficit, and their implications. Kidney International 17, 423-429.

Howard, P. J., Wilde, W. S. \& Malvin, R. L. (1959). Localization of renal calcium transport; effect of calcium loads and of gluconate anion on water, sodium and potassium. American Journal of Physiology 197, 337-341.

Intersalt Cooperative Research Group (1988). Intersalt: an international study of electrolyte excretion and blood pressure. Results for 24 hour urinary sodium and potassium excretion. British Medical Journal 297, 319-328.

Jubiz, W., Canterbury, J. M., Reiss, E., Tyler, F. H., Frailey, J., Bartholomew, K. \& Creditor, M. A. (1972). Circadian rhythm in serum parathyroid hormone concentration in human subjects: correlation with serum calcium, phosphate, albumin, and growth hormone levels. Journal of Clinical Investigation 51, 2040-2046.

King. J. S., Jackson, R. \& Ashe, B. (1964). Relation of sodium intake to urinary calcium excretion. Investigative Urology 1, 555-560.

Kivirikko, K. (1970). Urinary excretion of hydroxyproline in health and disease. International Review of Connective Tissue Research 5, 93-163.

Kleeman, C. R., Bohannan, J., Bernstein, D., Ling, S. \& Maxwell, M. H. (1964). Effect of variations in sodium intake on calcium excretion in normal humans. Proceedings of the Society for Experimental Biology and Medicine 115, 29-32.

Klein, L., Lafferty, F. W., Pearson, O. H. \& Curtiss, P. H. (1964). Correlation of urinary hydroxyproline, serum alkaline phosphatase and skeletal calcium turnover. Metabolism 13, 272-284.

Law, L. K., Swaminathan, R. \& Donnan, S. P. B. (1988). Relationship between sodium excretion and calcium excretion in healthy subjects. Medical Science Research 16, 643.

Lemann, J., Adams, N. D. \& Gray, R. W. (1979). Urinary calcium excretion in human beings. New England Journal of Medicine 301, 535-541.

Lindsay, R. (1988). Sex steroids in the pathogenesis and prevention of osteoporosis. In Osteoporosis: Etiology, Diagnosis, and Management, pp. 333-358 [B. L. Riggs and L. J. Melton; editors]. New York: Raven Press.

McCarron, D. A., Pingree, P. A., Rubin, R. J., Gaucher, S. M., Molitch, M. \& Krutzik, S. (1980). Enhanced parathyroid function in essential hypertension : a homeostatic response to a urinary calcium leak. Hypertension 2, 162-168.

McCarron, D. A., Rankin, L. I., Bennett, W. M., Krutzik, S., McClung, M. R. \& Luft, F. C. (1981). Urinary calcium excretion at extremes of sodium intake in normal man. American Journal of Nephrology 1, 84-90.

McParland, B. E., Goulding, A. \& Campbell, A. J. (1989). Dietary salt affects biochemical markers of resorption and formation of bone in elderly women. British Medical Journal 299, 834-835.

Madden, A., Flynn, A. \& Cremin, F. M. (1983). Relationship between dietary sodium intake and urinary calcium excretion. In Research in Food Science and Nutrition, vol. 3, Human Nutrition, pp. 30-31 [J. V. McLoughlin and B. M. McKenna, editors]. Dublin: Boole Press (International Congress of Food Science and Technology 6)

Magliaro, D. B. (1983). Pulsatile secretion of parathyroid hormone in humans. Calcified Tissue International 35, 685.

Massey, L. K. \& Wise, K. J. (1984). The effect of dietary caffeine on urinary excretion of calcium, magnesium, sodium and potassium in healthy young females. Nutrition Research 4, 43-50.

Massry, S. G., Coburn, J. W., Chapman, L. W. \& Kleeman, C. R. (1967). Effect of NaCl infusion on urinary Ca and $\mathrm{Mg}$ during reduction in their filtered loads. American Journal of Physiology 213, 1218-1224.

Meyer, W. J., Transbol, I., Bartter, F. C. \& Delea, C. (1976). Control of calcium absorption : effect of sodium chloride loading and depletion. Metabolism 25, 989-993.

Modlin, M. (1967). The aetiology of renal stone; a new concept arising from studies on a stone-free population. Annals of the Royal College of Surgeons 40, 155-177.

Muldowney, F. P., Freaney, R. \& Moloney, M. F. ([982). Importance of dietary sodium in the hypercalciuria syndrome. Kidney International 22, 292-296.

National Research Council (1978). Nutrient Requirements of Laboratory Animals, 3rd revised ed. Washington, DC: National Academy of Sciences. 
Nordin, B. E. C. \& Polley, K. J. (1987). Metabolic consequences of the menopause: a cross-sectional, longitudinal and intervention study on 557 normal postmenopausal women. Calcified Tissues International 41, S1-.S59.

Parfitt, A. M. (1969). The acute effects of mersalyl, chlorothiazide and mannitol on the renal excretion of calcium and other ions in man. Clinical Science 36, 267-282.

Phillips, M. J. \& Cooke, J. N. C. (1967). Relation between urinary calcium and sodium in patients with idiopathic hypercalciuria. Lancet i. $1354-1357$.

Sabto, J., Powell, M. J., Breidahl, M. J. \& Gurr, F. W. (1984). Influence of urinary sodium on calcium excretion in normal individuals. Medical Journal of Australia 140, 354-356.

Schaafsma, G. (1983). The significance of milk as a source of dietary calcium. International Dairy Federation Bulletin, Document 166, pp. 19-32.

Schaafsma, G., Van Beresteyn, E. C. H., Raymakers, J. A. \& Duursma, S. A. (1987). Nutritional aspects of osteoporosis. World Review of Nutrition and Dietetics 49, 121-159.

Shortt, C., Flynn, A. \& Morissey, P. A. (1987). Effect of dietary sodium chloride supplements on mineral metabolism in the rat. Irish Journal of Food Science and Technology 11, 186.

Shortt, C., Flynn, A. \& Morrissey, P. A. (1988). Influence of dietary sodium intake on urinary calcium excretion in selected Irish individuals. European Journal of Clinical Nutrition 42, 595-603.

Silver, J., Rubinger, D., Friedlaender, M. M. \& Popovtzer, M. M. (1983). Sodium-dependent idiopathic hypercalciuria in renal-stone formers. Lancet ii, 484-486.

Sjoerdsma, A., Udenfriend, S., Keiser, H. \& LeRoy, E. C. (1965). Hydroxyproline and collagen metabolism: clinical implications. Annals of Internal Medicine 63, 672-694.

Slatopolsky, E., Martin, K., Morrissey, J. \& Hruska, K. (1982). Current concepts of the metabolism and radioimmunoassay of parathyroid hormone. Journal of Laboratory and Clinical Medicine 99, 309-316.

Spencer, H. \& Kramer, L. (1986). The calcium requirement and factors causing calcium loss. Federation Proceedings 45, 2758-2762.

Spencer, H., Kramer, L. \& Osis, D. (1982). Factors contributing to calcium loss in aging. American Journal of Clinical Nutrition 36, 776-787.

Suki, W. N. (1979). Calcium transport in the nephron. American Journal of Physiology 237, F1-F6.

Sutton, R. A. L. \& Dirks, J. H. (1977). Renal handling of calcium: overview. In Phosphate Metabolism, pp. 15-27 [S. G. Massry and E. Ritz, editors]. New York: Plenum Press (Advances in Experimental Medicine and Biology 81).

Taylor, A. K., Lundy, M. W., Libanati, C. R. \& Baylink, D. J. (1988). Diagnostic tests for metabolic bone and mineral disorders. In Metabolic Bone and Mineral Disorders, pp. 33-62 [S. C. Manolagas and J. M. Olefsky, editors]. New York: Churchill Livingstone.

Walser, M. (1961). Calcium clearance as a function of sodium clearance in the dog. American Journal of Physiology 200, 1099-1104.

Zemel, M. B., Gualdoni, S. M., Walsh, M. F., Komanicky, P., Standley, P., Johnson, D., Fitter, W. \& Sowers, J. R. (1986). Sodium excretion and plasma renin activity in normotensive and hypertensive black adults as affected by dietary calcium and sodium. Journal of Hypertension 4, S364-S366. 